\title{
INOVASI PENGEMBANGAN MATERI PELAJARAN \\ BAHASA ASING TINGKAT MADRASAH TSANAWIYAH \\ BERBASIS WHITEBOARD ANIMATION
}

\author{
Najahah \\ Institut Agama Islam Negeri Kediri \\ najahahmudzakkir6@gmail.com \\ Ulin Ni'mah Rodliya Ulfah \\ Institut Agama Islam Negeri Kediri \\ ulinni'mah@iainkediri.ac.id
}

\begin{abstract}
Technology and foreign language are two related things. Mastery in the above two is a must for academic people, either for the teachers or the students. It is because, majority, the learning activity are done with the help of digital technology and foreign language. Technology is created in order to help human activity and also to improve the goals' achievement. While in the teaching and learning process, students tend to understand the material more if it is delivered in the form of picture, movie, video or animation. The foreign learning, nowaday, is considered unsatisfied since the material delivered is monotone and less in touch with the technology, so it is not really attractive. Second, the learning materials are assosiated more with textbook. While actually, the learning materials can be in the form of dictionary, cassette, video, worksheet and so on. Based on the above fact, the researcher improve the foreign (English and Arabic) learning materials for Islamic Junior High School based on whiteboard animation.
\end{abstract}

Keywords: The Innovation of Learning Material, Islamic Junior High School, the Foreign Language Learning, Whiteboard Animation. 


\section{Abstrak}

Teknologi dan bahasa asing adalah dua hal yang saling berkesinambungan. Penguasaan dua materi tersebut menjadi sebuah keniscayaan bagi sivitas akademika baik pendidik maupun siswa. Hal ini karena, mayoritas kegiatan pembelajaran berhubungan dengan alat-alat digital dan bahasa asing dalam penyampaiannya. Teknologi diciptakan untuk mempermudah usaha manusia, selain itu ia juga dapat meningkatkan pencapaian tujuan. Dalam pengajaran bahasa asing, siswa cenderung lebih mudah memahami materi jika disampaikan dalam bentuk gambar, film, video ataupun animasi. Pengajaran bahasa Asing saat ini masih dianggap kurang memuaskan karena materi yang disampaikan terlalu monoton dan kurang bersentuhan dengan teknologi sehingga kurang menarik untuk disampaikan. Kedua, materi ajar lebih banyak diasosiasikan dengan buku teks pelajaran. Padahal sebenarnya materi ajar dapat berupa kamus, kaset, video, lembar kerja, dan sebagainya. Berdasarkan hal-hal di atas, maka peneliti mengembangkan materi pelajaran Bahasa Asing pada Madrasah Tsanawiyah berbasis Whiteboard Animation.

Kata Kunci: Inovasi Bahan Ajar, Pendidikan Madrasab Tsanawiyah, Pembelajaran Babasa Asing, Whiteboard Animation.

\section{Pendahuluan}

Teknologi dan bahasa asing adalah dua hal yang tidak bisa dipisahkan dalam mencapai kesuksesan seseorang. Penguasaan dua materi tersebut menjadi keharusan bagi sivitas akademika baik guru maupun siswa dikarenakan saat ini semua kegiatan pembelajaran pasti berhubungan dengan alat-alat digital dan bahasa asing dalam penyampaiannya. Teknologi diciptakan untuk mempermudah usaha manusia, selain itu ia juga dapat meningkatkan pencapaian tujuan. Dalam pengajaran bahasa asing, siswa akan lebih mudah memahami materi jika disampaikan dalam bentuk gambar, film, video ataupun animasi. Penelitian terdahulu menyebutkan bahwa terjdi peningkatan pada kemampuan berbicara dengan menggunakan video youtube sebagai media pembelajaran pada siswa kelas delapan MTs PSM Mirigambar Tulungagung. ${ }^{1}$

Pengajaran Bahasa Inggris sebagai bahasa Asing saat ini masih dianggap kurang memuaskan karena materi yang disampaikan terlalu monoton dan kurang bersentuhan dengan teknologi sehingga kurang menarik untuk disampaikan. Selain

${ }^{1}$ Lia Selfia, "The Effectiveness of Using Video Youtube towards Students' Speaking Ability at the Second Grade of MTS PSM Mirigambar Tulungagung," Skripsi (IAIN Tulungagung, 2015). 
itu, materi ajar selalu diasosiasikan dengan buku teks pelajaran-padahal buku teks pelajaran hanya salah satu di antaranya. Materi ajar adalah apa saja yang dapat digunakan oleh guru dan siswa untuk memfasilitasi pembelajaran. Dengan demikian, materi ajar dapat berupa kamus, kaset, video, lembar kerja, dan sebagainya.

Dalam kurikulum 2013 dinyatakan bahwa bahasa Inggris adalah sebuah mata pelajaran inti dengan jumlah jam hanya 4 jam x 40 menit dalam satu minggu. Dengan sistem pengajaran yang biasa dan banyaknya jam yang dilakukan membuat guru bahasa Inggris tidak sempat membuat materi pembelajaran yang menarik. Hal ini berdampak pada tingkat penyerapan dan pemahaman peserta didik dalam pelajaran tersebut. Bahasa Arab pun sebagai bahasa asing memiliki nasib yang sama. Satu guru bahasa Arab juga mengajar dengan jumlah jam yang tinggi membuat ia tidak memiliki waktu untuk menyiapkan materi pembelajaran yang menarik sehingga pencapaian nilai bahasa Arab pun rendah. ${ }^{2}$

Masalah lain yang muncul adalah terbatasnya penguasaan guru-guru bahasa asing tersebut dalam membuat media pembelajaran dengan menggunakan teknologi seperti komputer dengan program-program menariknya. Mereka jarang sekali mneggunakan media pembelajaran yang berbasis teknologi karena ketidaktahuan akan program yang digunakan dan juga pengoperasiannnya. ${ }^{3}$ Cara mengajar yang monoton, kaku, dan kuno membuat penyerapan bahasa asing menjadi rendah sehingga anak-anak merasa bosan dan tidak maksimal dalam pencapaiannya. Sebagaimana diketahui teknologi informasi adalah hal yang tidak bisa lepas dari kehidupan sehari-hari. Berbagai kegiatan dilakukan dengan menggunakannya. Sementara mengajar bahasa asing pada anak-anak di tingkat sekolah menengah pertama adalah tantangan besar sehingga dibutuhkan suatu cara dan media untuk menarik dan memancing kreativitas dalam pengajarannya.

Melihat kenyataan di atas, maka peneliti mengembangkan materi pelajaran bahasa asing pada sekolah Islam atau madrasah tingkah tsanawiyah berbasis whiteboard animation, yang diharapkan dapat bermanfaat dalam kegiatan belajar mengajar bahasa asing (Inggris dan Arab).

\footnotetext{
${ }^{2}$ Hasil pre-leminary study di MTs. al-Hikmah Purwoasri Kediri pada 27 Juli 2019.

${ }^{3}$ Hasil pre-leminary study.
} 


\section{Kurikulum K13 SMP}

Struktur kurikulum menggambarkan konseptualisasi konten kurikulum dalam bentuk mata pelajaran, posisi konten/mata pelajaran dalam kurikulum, dostribusi konten/mata pelajaran dalam semester atau tahun, beban belajar untuk mata pelajaran dan beban belajar per minggu untuk setiap siswa. Struktur kurikulum adalah juga merupakan aplikasi konsep pengorganisasian konten dalam sistem belajar dan pengorganisasian beban belajar dalam sistem pembelajaran. Pengorganisasian konten dalam sistem belajar yang digunakan untuk kurikulum yang akan datang adalah sistem semester sedangkan pengorganisasian beban belajar dalam sistem pembelajaran berdasarkan jam pelajaran per semester. Struktur kurikulum juga gambaran mengenai penerapan prinsip kurikulum mengenai posisi seorang siswa dalam menyelesaikan pembelajaran di suatu satuan atau jenjang pendidikan.

Dalam struktur kurikulum menggambarkan ide kurikulum mengenai posisi belajar seorang siswa yaitu apakah mereka harus menyelesaikan seluruh mata pelajaran yang tercantum dalam struktur ataukah kurikulum memberi kesempatan kepada siswa untuk menentukan berbagai pilihan. Bahasa Inggris memiliki jam 4 jam dalam satu minggu. Struktur Kurikulum Bahasa Inggris K13 adalah masuk kelompok A di mana mata pelajaran yang memberikan orientasi kompetensi lebih kepada aspek kognitif dan afektif. Sedangkan Bahasa Arab menurut Struktur Kurikulum K13 untuk MTs seperti yang digunakan oleh madrasah penyelenggara Kurikulum 2013, termasuk dalam isian jadwal mengajar Simpatika, mengikuti struktur kurikulum dalam Keputusan Menteri Agama Nomor 165 Tahun 2015 tentang Pedoman Kurikulum Madrasah 2013 Mata Pelajaran PAI dan Bahasa Arab. Dalam peraturan tersebut, pelajaran bahasa Arab memiliki waktu 3 jam dalam seminggu.

\section{Inovasi Kurikulum}

Menurut Muhaimin, kata kurikulum berasal dari bahasa Yunani yang semula digunakan dalam bidang olahraga, ${ }^{4}$ yaitu currere yang berarti jarak tempuh lari, yakni

\footnotetext{
${ }^{4}$ Muhaimin, Pengembangan Kurikulum Pendidikan Agama Islam di Sekolah, Madrasab, dan Perguruan Tinggi (Jakarta: Rajawali Press, 2010).
} 
jarak yang harus ditempuh dalam kegiatan berlari mulai dari start hingga finish. Pengertian ini kemudian diterapkan dalam bidang pendidikan.

Sedangkan menurut Suparlan, ${ }^{5}$ secara terminologis istilah kurikulum yang digunakan dalam dunia pendidikan mengandung pengertian sebagai sejumlah pengetahuan atau mata pelajaran yang harus ditempuh atau diselesaikan siswa untuk mencapai satu tujuan pendidikan atau kompotensi yang diterapkan sebagai tanda atau bukti bahwa peserta didik telah mencapai standar komptensi dengan sebuah ijazah atau sertifikat yang diberikan kepada peserta didik.

Dalam Undang-Undang Nomor 20 Tahun 2003 tentang Sistem Pendidikan Nasional, Bab I pasal 1 ayat 19, disebutkan kurikulum adalah seperangkat rencana dan pengaturan mengenai tujuan, isi dan bahan pelajaran serta cara yang digunakan sebagai pedoman penyelenggaraan kegiatan pembelajaran untuk mencapai tujuan pembelajaran tertentu.

Kurikulum merupakan salah satu indikator yang menentukan berhasil tidaknya suatu pendidikan sehingga perlu adanya pengembangan kurikulum. Istilah pengembangan (development) berarti pengelolaan frase-frase dan motif-motif dengan detail terhadap tema. ${ }^{6}$ Jadi, pengembangan kurikulum merupakan suatu proses merencanakan, menghasilkan suatu alat yang lebih baik dengan didasarkan atas hasil penilaian terhadap kurikulum yang telah berlaku sehingga dapat memberikan kondisi belajar mengajar yang lebih baik. ${ }^{7}$ Dengan kata lain, pengembangan kurikulum adalah kegiatan untuk menghasilakan kurikulum baru melalui langkah-langkah penyusunan kurikulum atas dasar hasil penilaian yang dilakukan selama periode waktu tertentu.

\section{Pengembangan Kurikulum}

Kurikulum merupakan suatu alat untuk mencapai tujuan pendidikan dan pengajaran yang dicetuskan dan ditetapkan oleh sekolah secara dinamis dan progresif.

\footnotetext{
${ }^{5}$ Suparlan, Tanya Jawab Pengembangan Kurikulum Materi Pembelajaran (Jakarta: Bumi Aksara, 2010).

${ }^{6}$ Kamarudin dan Yooke Tjuparman, Kamus Istilah Karya Tulis Ilmiah (Jakarta: Bumi Aksara, 2000), 186.

${ }^{7}$ Ahmad et al., Pengembangan Kurikulum (Bandung: CV Pustaka Setia, 1998).
} 
Hal ini berarti, bahwa kurikulum harus selalu dikembangkan dan disempurnakan agar sesuai dengan perkembangan ilmu pengetahuan dan teknologi, serta masyarakat yang sedang membangun. Sedangkan isi pendidikan yang dimaksudkan adalah materi kurikulum yang disusun oleh guru. Dalam Undang-Undang Sisdiknas bab IX pasal 39 telah ditetapkan bahwa: isi kurikulum merupakan bahan kajian dan pelajaran untuk mencapai tujuan penyelenggaraan satuan pendidikan yang bersangkutan dalam rangka upaya mencapai tujuan pendidikan nasional.

Dalam rangka pengembangan kurikulum perlu diperhatikan beberapa komponen, yang menurut Nasution antara lain: tujuan, bahan pelajaran, proses belajar mengajar, dan penilaian. ${ }^{8}$

Dari pendapat di atas dapat diketahui bahwa pengembangan kurikulum dapat dilakukan berdasarkan komponen-komponen tersebut. Ada yang dikembangkan dari sisi tujuan dan materinya, tetapi ada yang hanya dari segi metodenya saja, atau organisasinya saja.

\section{Aplikasi Whiteboard Animation}

Whiteboard animation adalah media komunikasi yang dibuat oleh si pengirim kepada penerimatanda melalui simbol-simbol yang adadi whiteboard animation. Dengan adanya simbol-simbol seperti kata-kata, kalimat disertai gambar dan audiovisual akan membantu penerima tanda dengan mudah memahamiapa yang hendak dipesankan oleh pengirim. White board animation ini menggunakan Videoscribe yanga mana adalah software yang bisa kita gunakandalam membuat desain animasi berlatar putih (whiteboard animation) dengan sangat mudah. Software ini dikembangkan pada tahun 2012 oleh Sparkol-salah satu perusahaan yang ada di Inggris.

Dengan adanya Videoscribe-Sparkol, kita bisa menyajikan sesuatu yang panjang menjadi tidak terlalu panjang. Kita bisa menyajikan perasaan kita diserta gambar yang akan memperjelas sistem komunikasi antara pengirim dan penerima. Kegunaan Software Videoscribe

\footnotetext{
${ }^{8}$ S. Nasution, Asas-Asas Kurikulum, Cet. VII (Jakarta: BumiAksara, 2006), 18.
} 
- Videoscribe bisa digunakan untuk keperluan bisnis online.

- Ide marketing bisa diaplikasikan lewat videoscribe.

- Videoscribe bisa digunakan untuk pendidik/guru atau dosen sebagai pengantar pembelajaran

- Videoscribe untuk presentasi keperluan.

- Menunjukkan kemampuan berpikir dan mengkombinasikannya melewati video animasi.

- Dan masih banyak lagi eksperimen-eksperimen yang bisa kita gunakan dengan software ini.

Software ini dipilih karena mudah penggunaannya dan cara pengoperasiannya juga sangat mudah sehingga dapat digunakan oleh guru-guru bahasa Arab dan Inggris tingkat madrasah tsanawiyah.

\section{Implementasi Inovasi Pengembangan Materi}

Dengan demikian, penelitian ini adalah penelitian yang mengembangkan dan memvalidasi produk pendidikan yang didahului oleh penelitian-penelitian sebelumnya untuk sebuah produk yang dikembangkan. Dari produk ini ini kemudian diujicobakan secara berkala, kemudian direvisi yang dalam bentuk yang benar dan sampai pada produk jadi yang tepat.

Implementasi metode penelitian yang digunakan oleh penulis mengacu pada prosedur yang dikembangkan oleh Sugiyono ke tahapan-tahapan sebagai berikut: 


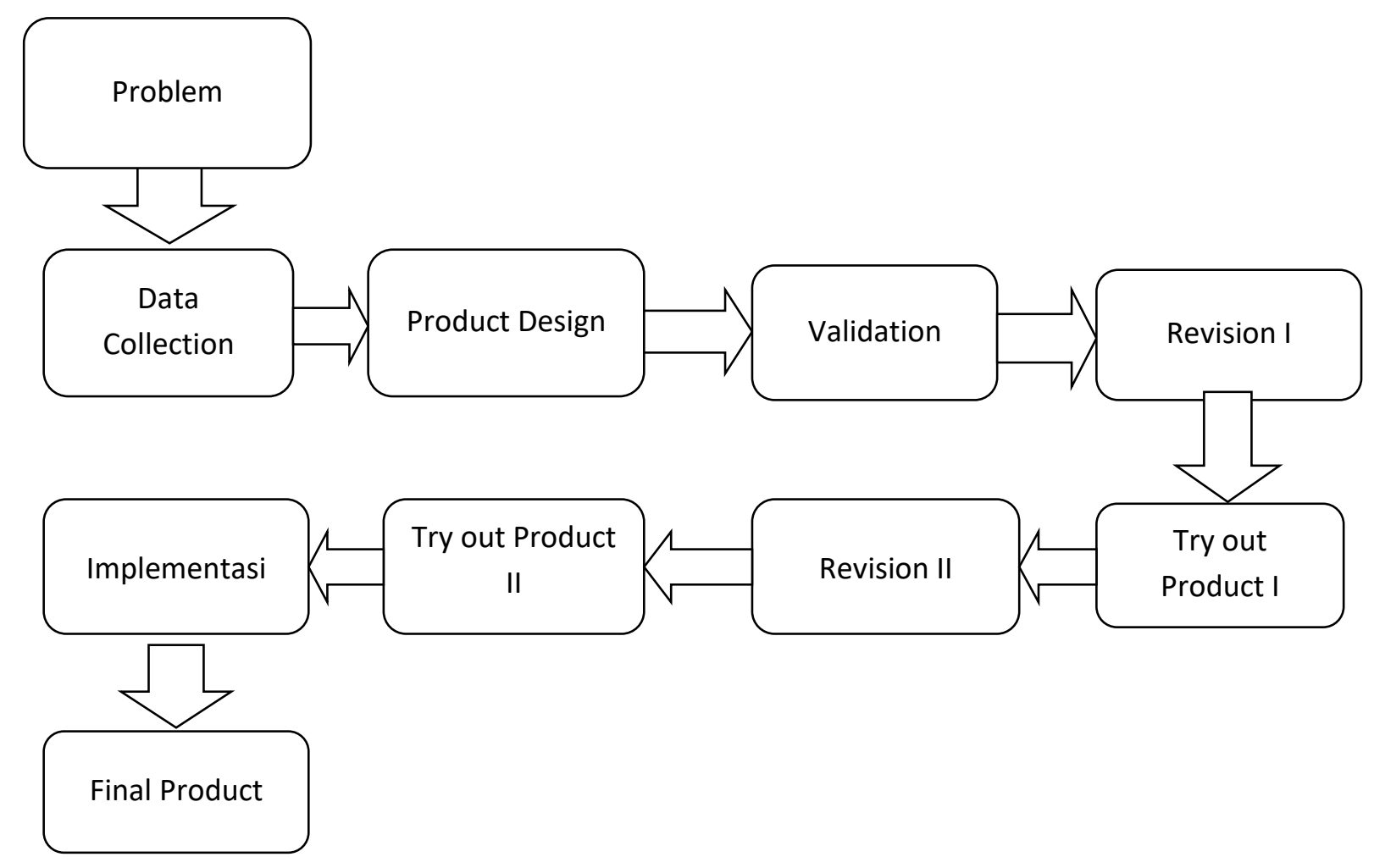

Mengacu pada model pengembangan implementasi metode penelitian R\&D Sugiyono, ${ }^{9}$ peneliti mengambil langkah-langkah dalam proses ini dengan beberapa pertimbangan untuk menyesuaikan karakteristik, keterbatasan waktu, tenaga dan biaya. Langkah-langkah yang diambil adalah sebagai berikut:

a. Masalah pada langkah ini dilakukan tinjauan pustaka, analisis problem di lapangan, identifikasi masalah yang dihadapi dalam pembelajaran, dan merangkum masalah.

b. Pengumpulan data dilakukan dengan wawancara, observasi, kuesioner dan dokumentasi untuk mendapatkan data yang akurat dan cocok untuk diproses dalam penelitian, terutama sebagai bahan untuk merancang dan membangun produk yang diharapkan dapat mengatasi masalah yang ada.

c. Desain produk; desain produk adalah hasil akhir dari serangkaian penelitian awal, dalam penelitian ini hasil akhir dari program. Desain program ini adalah naskah kurikulum dan video berbasis white animaion.

\footnotetext{
${ }^{9}$ Sugiyono, Metode Penelitian Kuantitatif, Kualitatif dan $R \& D$ (Bandung: Alfabeta, 2009).
} 
d. Validasi adalah serangkaian kegiatan yang meliputi validasi materi dan validasi program. Validasi dilakukan untuk menilai desain produk, proses ini mencakup penilaian ahli multi media, ahli materi/isi, dan ahli bahasa.

e. Revisi I dibuat setelah kelemahan desain yang diketahui atau disarankan oleh validator.

f. Uji Coba. Percobaan produk-produk yang dilakukan pada subjek percobaan untuk memeriksa produk layak atau tidak.

g. Revisi II dilakukan setelah produk dicoba setelah revisi.

h. Uji Coba II adalah untuk mencoba produk revisi.

i. Revisi III diterapkan untuk membuat program sempurna.

j. Produk akhir adalah produk lengkap yang telah dievaluasi oleh validator.

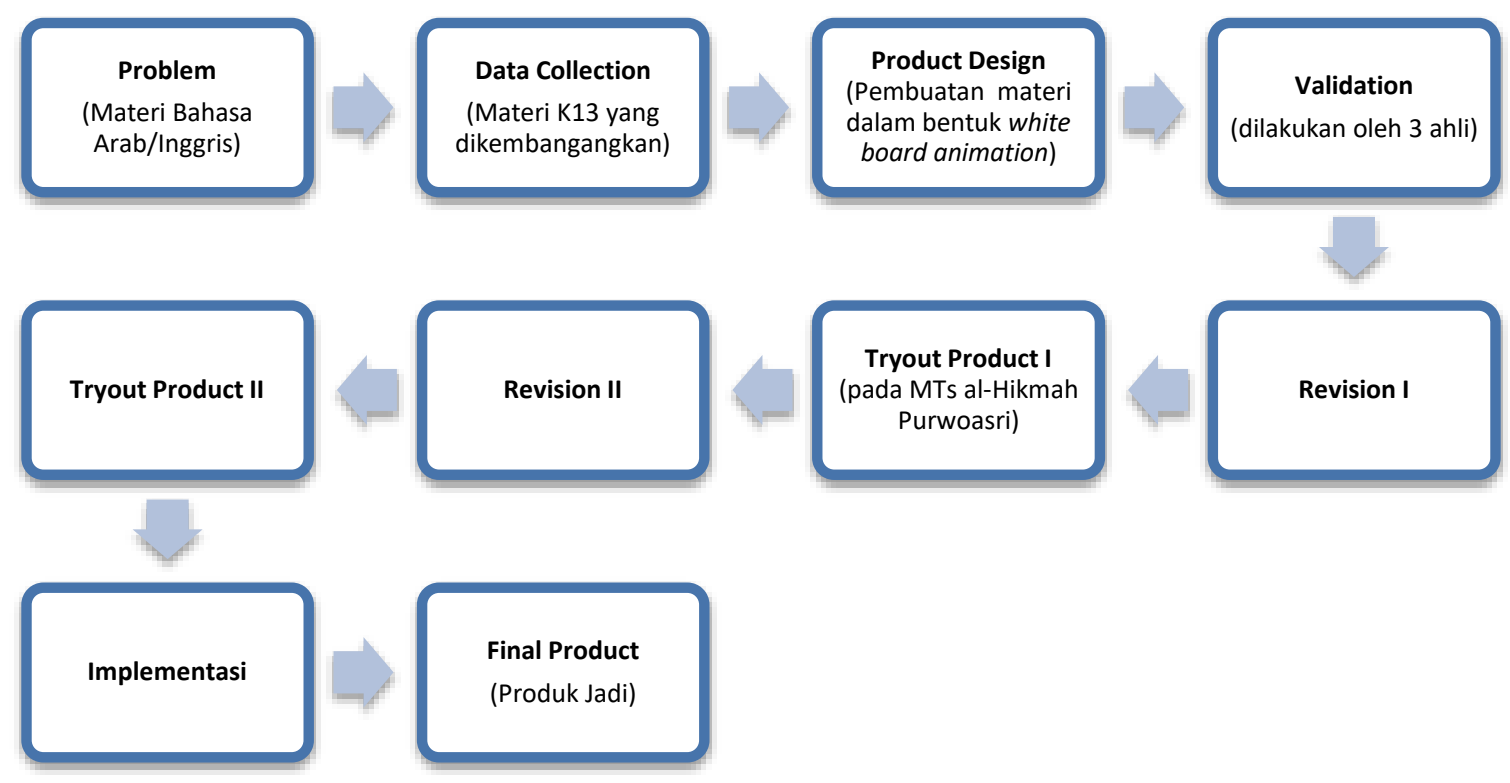

\section{Tampilan}

Perancangan tampilan dimaksudkan untuk memberikan tampilan antarmuka tentang perancangan program yang akan dibuat. Tujuan dari perancangan antarmuka adalah pengguna perancangan antarmuka yang efektif untuk produk yang dibuat. Pengguna sering menilai aplikasi dari antarmuka pengguna. Jika desain antar muka pengguna jelek, maka hal itu sering menjadi alasan untuk mengecilkan hati pengguna meggunakan aplikasi. 


\section{Validasi}

Validasi produk dapat dilakukan dengan menghadirkan beberapa pakar yang berpengalaman menilai produk baru. Setiap ahli diminta menilai desainnya, sehingga dapat diketahui kelemahan dan kekurangannya. ${ }^{10}$ Dalam proses validasi digunakan kuesioner untuk mengumpulkan data. Sebelum membuat kuisioner, siapkan terlebih dahulu kisi-kisi. Yang dimaksud dengan kisi-kisi dalam rangkaian adalah semacam proses tabel kolom baris instrumen yang memberikan gambaran tentang hubungan antara objek sasaran evaluasi, instrumen, dan jumlah item dalam instrumen. ${ }^{11}$

Terdapat tiga validator pada penelitian ini. Pertama, validator isi, yang dalam penelitian ini adalah dosen Bahasa Inggris IAIN Kediri yang bersedia menilai kelayakan bahan ajar yang telah dirancang. Kedua, ahli multimedia aykni dua ahli multimedia diperiksa. Dua orang ahli dari UNP dan SMPN 1 Grogol Kediri. Ketiga, validasi bahasa, yakni juga dilakukan oleh validator bahasa dosen bahasa Arab dan bahasa Inggris IAIN Kediri yang bersedia menilai kelayakan bahan ajar yang telah dirancang.

\section{Teknik Analisis Data}

Kelayakan suatu bahan ajar dapat dilihat dari polling data yang digunakan. Nilai kelayakan media tersebut berdasarkan kelayakan skala likert sebagai berikut:

\begin{tabular}{|c|c|}
\hline Ratings & Value \\
\hline Strongly Worthy & $4,00-5,00$ \\
\hline Worthy & $3,00-3,99$ \\
\hline Less Worthy & $2,00-2,99$ \\
\hline Not Worthy & $1,00-1,99$ \\
\hline
\end{tabular}

${ }^{10}$ Sugiyono, Metode Penelitian Kuantitatif, Kualitatif dan $R \& D, 302$.

11 Suharsimi Arikunto dan Cepi S.A. Jabar, Evaluasi Program Pendidikan Pedoman. Teoritis Praktis bagi Mahasiswa dan Praktisi Pendidikan (Jakarta: Bumi. Aksara, 2009), 98. 


\section{Program Pemahaman Mendengarkan Interaktif}

Program Pemahaman Mendengarkan Interaktif merupakan hasil atau produk akhir. Pada tampilannya menampilkan halaman pembuka yang terdiri dari nama program "Pemahaman Mendengarkan Interaktif" dan "masuk" untuk memulai program "menu" untuk masuk ke submenu. Berikut gambar halaman depan program ini.

Di halaman menu utama, terdapat enam tombol, "submenu" untuk halaman materi, "Pilihan ganda" untuk mendengarkan pilihan ganda, praktikkan "Dikte" pada menu dikte, "Lirik yang Hilang" untuk mengisi kata, dan "Film" untuk melihat film Inggris "Keluar" untuk keluar.

\section{Materi Tampilan Halaman Bahasa Arab}

Materi tampilan halaman terdiri dari 8 judul yang dapat dipilih dengan mengklik salah satu judul sekaligus instruksi untuk menjawab pertanyaan yang ada dengan mengklik salah satu jawaban.

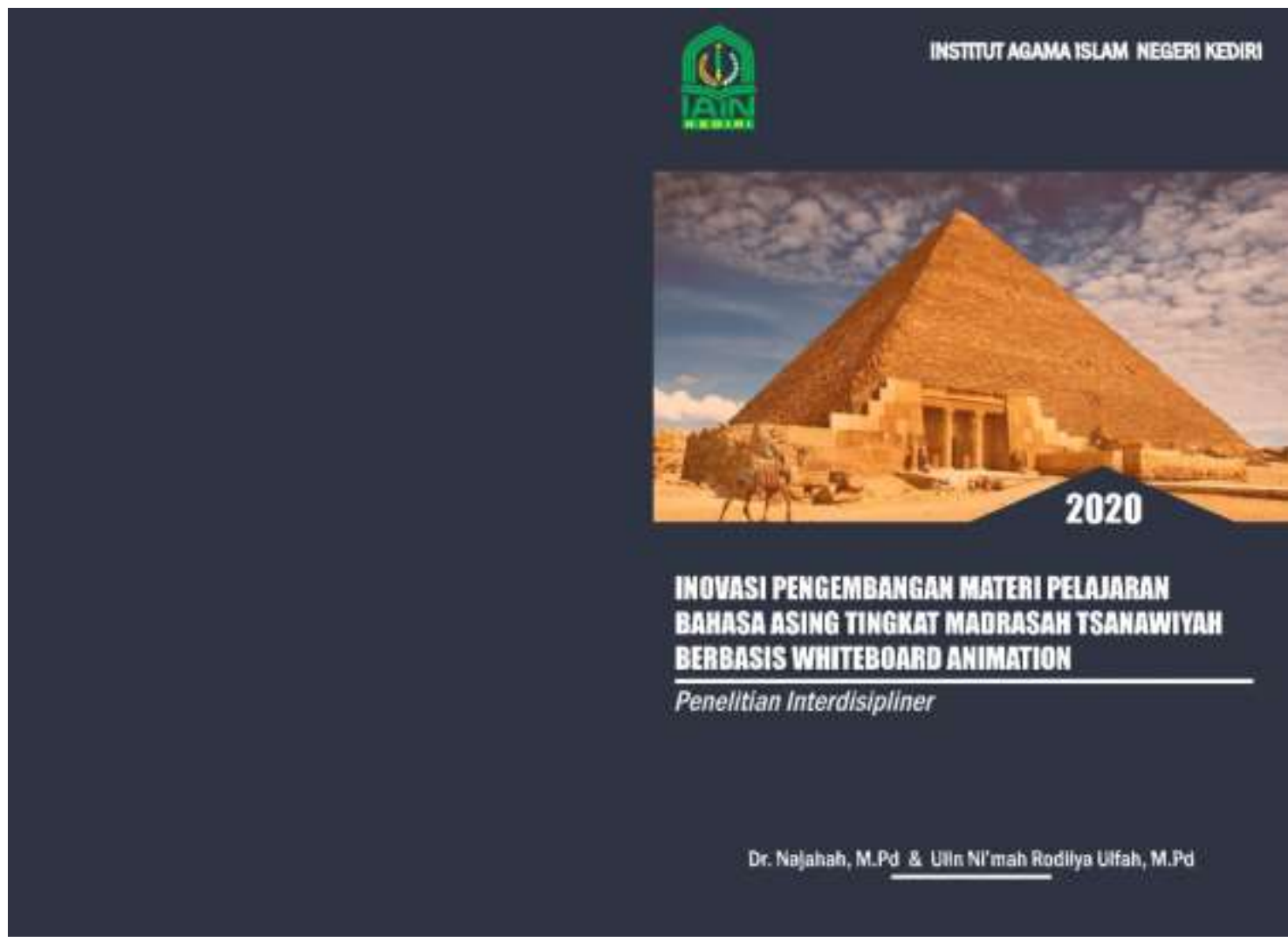


Najahah E Ulin Ni'mah Rodliya Ulfah, Inovasi Pengembangan Materi Pelajaran ...
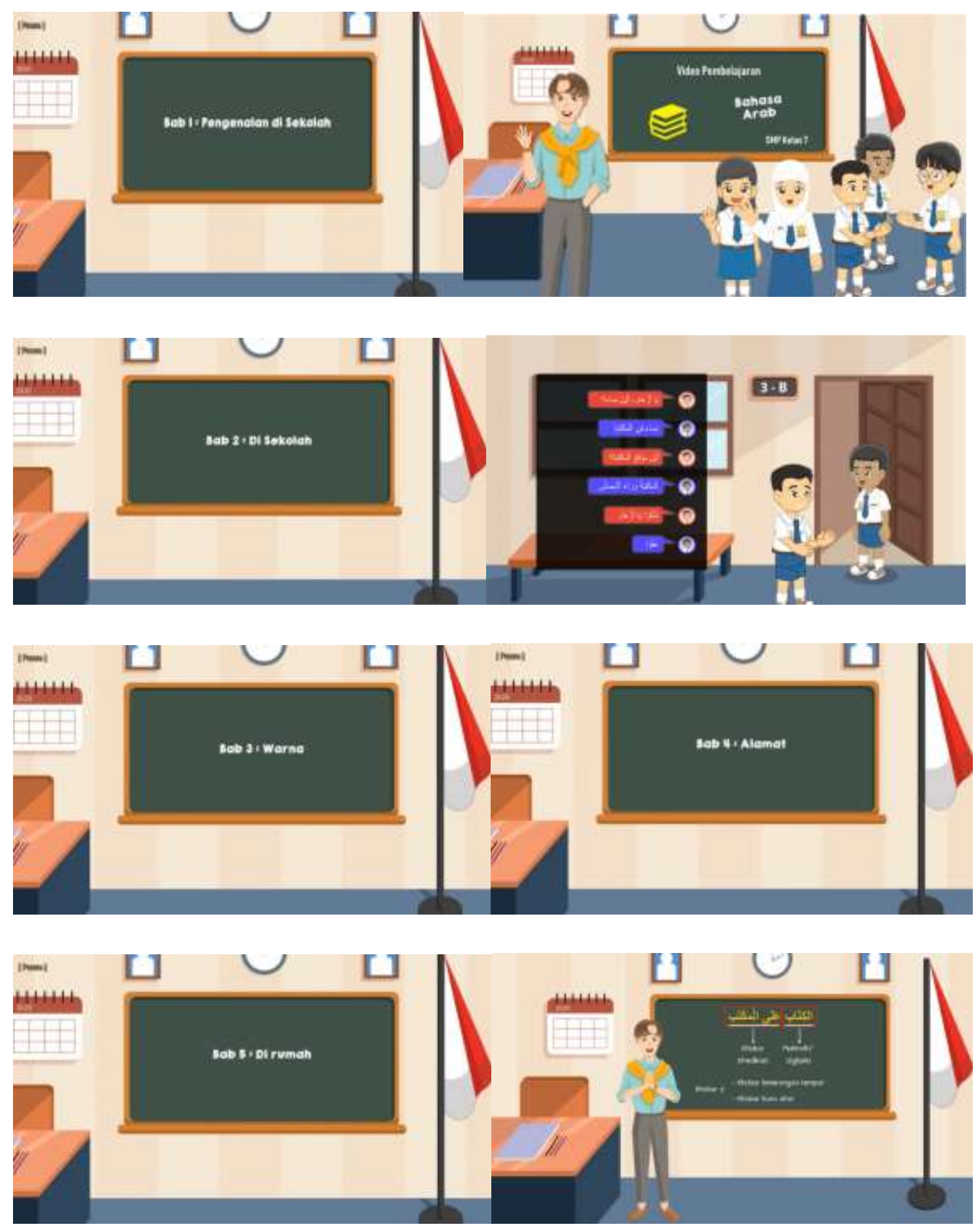

\section{Materi Tampilan Halaman Bahasa Inggris}

Materi tampilan halaman terdiri dari 8 judul yang dapat dipilih dengan mengklik salah satu judul. Sekaligus instruksi untuk menjawab pertanyaan yang ada dengan mengklik salah satu jawaban. 

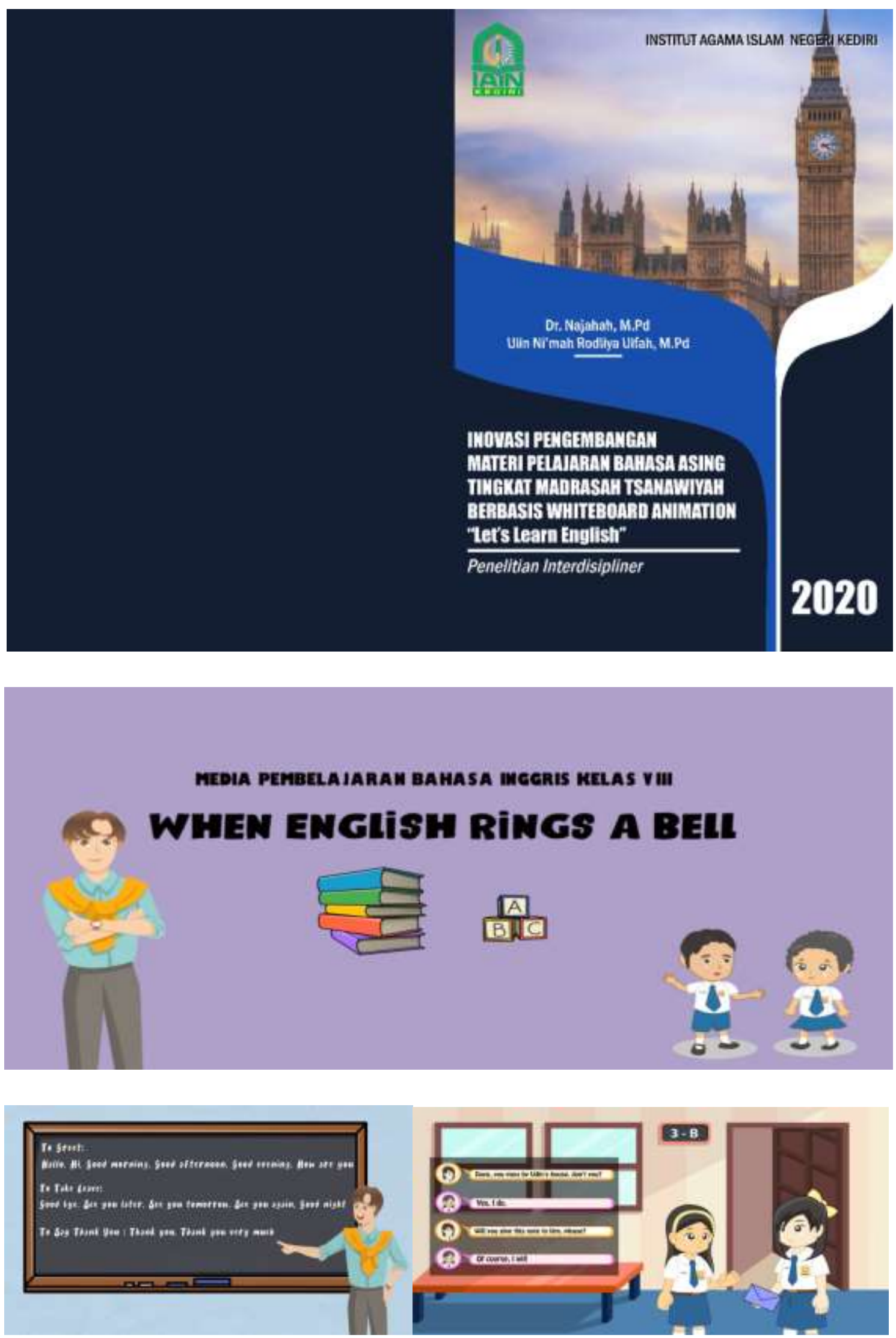


\section{Simpulan}

Penggunaan teknologi dalam pembelajaran dapat mendukung inovasi pengembangan materi pelajaran bahasa asing. Pengembangan ini juga sejalan dengan kurikulum dan peningkatan pendidikan sekolah Islam atau madrasah tingkat tsanawiyah. Dengan menggunakan media whiteboard animation dalam pembelajaran, peserta didik cenderung lebih mudah memahami materi jika disampaikan dalam bentuk gambar, film, video ataupun animasi. Dengan demikian, inovasi pengembangan materi pelajaran bahasa asing tersebut dapat menjadi tawaran dalam pengajaran bahasa Asing yang saat ini masih dianggap kurang memuaskan karena materi yang disampaikan terlalu monoton dan kurang menarik.

\section{Daftar Pustaka}

Ahmad et al., Pengembangan Kurikulum. Bandung: CV. Pustaka Setia, 1998.

Arikunto, Suharsimi dan Cepi S.A. Jabar. Evaluasi Program Pendidikan Pedoman.

Teoritis Praktis bagi Mahasiswa dan Praktisi Pendidikan. Jakarta: Bumi. Aksara, 2009.

Hamalik, Oemar. Kurikulum dan Pembelajaran. Jakarta: Bumi Aksara, 2010.

Kamarudin dan Yooke Tjuparman. Kamus Istilah Karya Tulis Ilmiah. Jakarta: Bumi Aksara, 2000.

sKeputusan Menteri Agama Nomor 165 Tahun 2015 tentang Pedoman Kurikulum Madrasah 2013

Muhaimin. Pengembangan Kurikulum Pendidikan Agama Islam di Sekolah, Madrasah, dan Perguruan Tinggi. Jakarta: Rajawali Press, 2010.

Nasution, S. Asas-Asas Kurikulum, Cet. VII. Jakarta: BumiAksara, 2006.

Sukmadinata, Nana Syaodih. Pengembangan Kurikulum: Teori dan Praktik. Bandung: Remaja Rosdakarya, 2008.

Selfia, Lia. "The Effectiveness of Using Video Youtube towards Students' Speaking Ability at the Second Grade of MTS PSM Mirigambar Tulungagung.” Skripsi (IAIN Tulungagung, 2015). 
Al-'Adalah, Vol. 23, No. 2 (2020)

Sugiyono. Metode Penelitian Kuantitatif, Kualitatif dan RED. Bandung: Alfabeta, 2009.

Subandiyah. Pengembangan dan Inovasi Kurikulum. Jakarta: Grafindo Persada, 1993.

Suparlan. Tanya Jawab Pengembangan Kurikulum Materi Pembelajaran. Jakarta: Bumi Aksara, 2010.

Undang-Undang Nomor 20 Tahun 2003 tentang Sistem Pendidikan Nasional. 